Article

\title{
It Depends...Different Direct Democratic Instruments and Equality in Europe from 1990 to 2015
}

\author{
Brigitte Geißel *, Anna Krämling and Lars Paulus \\ Research Unit Democratic Innovations, Goethe University Frankfurt, 60323 Frankfurt, Germany; E-Mails: \\ geissel@soz.uni-frankfurt.de (B.G.), kraemling@soz.uni-frankfurt.de (A.K.), I.paulus@soz.uni-frankfurt.de (L.P.) \\ * Corresponding author
}

Submitted: 13 December 2018 | Accepted: 1 March 2019 | Published: 27 June 2019

\begin{abstract}
Despite the popularity of direct democracy in recent decades, research on the actual output effects of popular decisionmaking is rare. This is especially true with regard to equality, where there are at least three major research gaps: 1) a lack of cross-national analyses; 2 ) insufficient investigation of the differential effects of different direct democratic instruments on equality; and 3) a failure to distinguish between different aspects of equality, i.e., socioeconomic, legal and political equality. This article takes a first step to tackle these shortcomings by looking at all national referenda in European democracies between 1990 and 2015, differentiating between mandatory, bottom-up and top-down referenda. We find that a large majority of successful direct democratic bills-regardless of which instrument is employed-are not related to equality issues. Of the remaining ones, there are generally more successful pro-equality bills than contra-equality ones, but the differences are rather marginal. Mandatory referenda tend to produce pro-equality outputs, but no clear patterns emerge for bottom-up and top-down referenda. Our results offer interesting, preliminary insights to the current debate on direct democracy, pointing to the conclusion that popular decision-making via any type of direct democratic instrument is neither curse nor blessing with regard to equality. Instead, it is necessary to look at other factors such as context conditions or possible indirect effects in order to get a clearer picture of the impacts of direct democracy on equality.
\end{abstract}

\section{Keywords}

direct democracy; direct democratic instruments; equality; Europe

Issue

This article is part of the issue "The Politics, Promise and Peril of Direct Democracy", edited by Todd Donovan (Western Washington University, USA).

(C) 2019 by the authors; licensee Cogitatio (Lisbon, Portugal). This article is licensed under a Creative Commons Attribution 4.0 International License (CC BY).

\section{Introduction}

In light of declining conventional political participation and growing dissatisfaction with representative democracy all over the Western world, calls for an expansion of direct democratic options have become quite popular in recent times. Initiatives and referenda are perceived as a possible cure for the current "crisis of democracy" by increasing the involvement of citizens in political decision-making and thereby fostering their support for the political system in general (Bowler, Denemark, Donovan, \& McDonnell, 2017; Dalton, 2004). This has al- ready led to an increasing use of direct democratic options worldwide during the last 30 years. Likewise, parties not only from the left (cf. Michels, 2009), but across the ideological spectrum are campaigning to further enlarge those options.

However, the effects of direct democracy on society are far from being uncontroversial among political scientists. An important topic in this regard is the question of how direct democracy impacts equality within modern societies. Up to now, findings on this topic are mixed: some scholars acknowledge the potential of direct democratic instruments to foster equality (Feld, Fischer, \& 
Kirchgässner, 2010; Frey \& Goette, 1998; Garry, 2013), while others warn that they further increase the gap between already influential and non-influential citizens because they advantage the former in pursuing their interests (Merkel, 2011; Merkel \& Ritzi, 2017; Schäfer \& Schoen, 2013).

Possible explanations for these divergent findings could be that outputs differ depending on the direct democratic instrument, the concept of equality employed or the country investigated. The existing studies in this field find somewhat contradictory results with regard to different instruments and equality dimensions: while it has been reported that welfare expenditure tends to be lower in countries with mandatory referenda and to be higher in countries with national initiatives (hinting at possibly differing impacts regarding socioeconomic equality), legal and political rights of minorities seem to be better protected under mandatory referenda than under optional ones and initiatives (Blume, Müller, \& Voigt, 2009; Blume \& Voigt, 2012; Vatter \& Danaci, 2010).

Against this background, further investigation of the effects of different direct democratic instruments on equality, covering a wide range of countries as well as various dimensions of equality, is needed. This article, which is part of the DFG-funded project "Inequality and direct democracy", aims at taking a first step in this direction by looking at whether there are, at the national level, more successful pro- or contra-equality bills that passed via different direct democratic instruments during the last decades in European democracies. By doing so, we want to gain an overview of how many pro- and contra-equality outputs are produced by the different instruments. Clearly, the results of this article cannot give a definite answer to the question of how direct democracy influences equality, but they can give a first, preliminary overview of which sort of bills are successful in different direct democratic instruments and how they relate to equality.

For the purpose of our study we proceed as follows: we first outline our theoretical considerations regarding equality and its dimensions, direct democracy in its differing forms, and the connection between the two. We proceed by providing an overview of the current literature on direct democracy and equality, pointing out existing research gaps. Afterwards, we present our case selection and coding approach to address the issue. In our result section, we compare the numbers of all successful pro- and contra-equality bills that were put to a direct democratic vote at a national level in European democracies from 1990 to 2015 . We draw on a dataset of all popular votes that took place in this time period and distinguish between mandatory, bottom-up and top-down referenda. We acknowledge that this research approach comes with certain limitations: first, we do not look-in detail-at the social and political context in which the referenda took place. Second, our research design does not allow for any inferences about a possible indirect effect of direct democracy with regard to equality. Third, our research design implies a causal impact of different direct democratic instruments on equality but does not allow for an infinite answer with regard to causality. In general, this article should be understood as a first attempt to get an idea of how many successful pro- and contra-equality bills pass via different direct democratic instruments in Europe-and if any interesting patterns emerge in this context. Our results reveal that a large majority of successful bills are not related to equality issues at all and therefore cannot be expected to have an impact in this regard. For any direct democratic instrument, there are relatively small differences with regard to the numbers of successful pro- and contra-equality bills. Still, the pattern emerges that there are slightly more successful proequality bills than contra ones and that especially mandatory referenda tend to produce pro-equality outputs. In the conclusion, we discuss how our results can serve as a basis for future research on the topic and give propositions for doing so.

\section{Theoretical Background}

Before investigating the outputs of different direct democratic instruments for equality, we need to address at least three issues from a theoretical perspective. First, we have to conceptualize our understanding of equality and its various dimensions. Second, we have to give a definition of direct democracy and its different instruments. Third, we have to explain why direct democracy possibly has an impact on equality and why different instruments might differ in their impact. The following paragraphs will address these issues.

First, regarding the conceptualization of equality, in the broadest sense this means a relationship between two or more reference objects (e.g., $A$ and $B$ ) with regard to a certain benchmark X (Alexy, 1986; Altwicker, 2011; Westen, 2016). The debate in the social sciences about how to conceptualize equality in a more narrow way revolves mainly around the concepts of "equality in result" and "equal opportunity" (Devins \& Douglas, 1998; Siegel, 1998; Strauss, 1992). We stick to the first understanding of equality as closing the gap between disadvantaged (A) and well-off groups (B) with regard to a certain benchmark $(X)$. We do this because in highly unequal societies, i.e., societies with large gaps between disadvantaged and well-off groups, equality of opportunity also tends to decrease. Or, in other words, closing the gap between different social groups within society will also enable and increase equal opportunities (see also Rawls, 1971, p. 278).

Sometimes it is necessary to treat groups unequally in order to foster equality in result-to give benefits to those who are worse off at the expense of those who are better off (Altwicker, 2011; Sartori, 1992). Therefore, all direct democratic bills that aim at making society more equal (by proposing equal or unequal treatment of certain social groups) are considered as pro-equality. 
As mentioned in the introduction, equality occurs in different dimensions. Regarding the effects of direct democracy, most of the literature focusses on aspects of socioeconomic equality. Another point of scientific interest are the implications of direct democratic options and decisions for minorities, containing issues of legal and political equality (see Section 3). We want to gain knowledge about direct democratic outputs for equality that is as encompassing as possible. Therefore, we include three dimensions of equality and define them in the following way:

1. Socioeconomic equality: equality regarding the socioeconomic status (SES; aspects such as income, education, health, or property);

2. Legal equality: equality regarding the legal status of the inhabitants of a country;

3. Political equality: equality regarding the scope of political influence (especially of minority groups).

Second, direct democracy is defined as popular votes on issues-excluding direct elections or recalls of politicians. Similar to Blume et al. (2009) and Blume and Voigt (2012), we differentiate between three different types of direct democratic instruments: bottom-up referenda (initiated by citizens, i.e., referenda against parliamentary decisions or new initiatives); top-down referenda (initiated by parliament or government); and mandatory referenda (specific laws-e.g., changes to the constitutionthat must be approved by a popular vote according to the constitution).

Third, as mentioned above, in the literature the questions of why and how direct democracy may be expected to have an effect on equality are generally approached from the socioeconomic perspective or with regard to $\mathrm{mi}-$ norities. One prominent argument, mainly linked to socioeconomic equality, is that low SES groups tend to lose in direct democratic decisions because disproportionally few poor people vote compared to well-off upper and middle classes. As a result, the decisions would mirror the socioeconomic interests of the better-off and therefore disadvantage low SES groups. This theoretical expectation of direct democracy decreasing socioeconomic equality is for example promoted by Wolfgang Merkel (Merkel, 2011; Merkel \& Ritzi, 2017).

This negative impact of direct democracy on socioeconomic equality might also be expected from the perspective of the median voter theorem (Black, 1948; Downs, 1957). Applied to direct democracy, it is assumed that outputs of direct democratic votes should generally mirror the preferences of the median voter. Increasing government spending on welfare, benefitting low SES groups, is probably not in line with the socioeconomic interests of a median voter, at least in relatively well-off countries with a large middle class.

Regarding the legal and political dimensions of equality, some scholars are more optimistic, once again arguing with the median voter perspective: in their view, the output of direct democracy for minorities should depend on the attitudes of the majority of the voters regarding the respective minority. Therefore, direct democracy is expected to lead to minority-friendlier policies if voters support these policies more than political decisionmakers do, and expected to disadvantage minorities if voters oppose minority-friendly ruling (Matsusaka, 2004; Töller \& Vollmer, 2013; Vatter \& Danaci, 2010). So, as attitudes towards certain minority groups may vary between different regions or countries, so may the outputs of direct democratic decisions in light of legal and political equality.

As discussed above, not only different dimensions of equality, also different direct democratic instruments should be taken into account. Eder and Magin (2008) imply that bottom-up referenda should be more protective of minority rights than the output of top-down ones. This is mainly because in the former case minorities can initiate votes as well as veto bills that would disadvantage them. While the study by Eder and Magin (2008) mainly deals with the legal and political equality of minorities, the same reasoning might also apply to socioeconomic equality-but in the opposite direction: bottom-up referenda might for the most part be initiated by well-off citizens with the financial resources to stem successful campaigns, presumably proposing policies in their interest instead of an extension of welfare programs. In contrast, bills in top-down and mandatory referenda are drafted by politicians who want to be re-elected, so at least some of them might address low SES groups.

Summing up, there are some ideas out there on why and how-different-direct democratic instruments might have an impact on equality, but the matter is far from clear. Moreover, one has to keep in mind that the theoretical approaches we have just briefly introduced build on the idea of a causal impact of direct democracy on equality. However, the other causal pathway must also be kept in mind, i.e., that certain levels of inequality within a society lead to a different use of direct democracy and also to different outputs in direct democratic votes. The aim of this article is not to test any causal relationship or make strong inferences about mechanisms on how exactly direct democracy might impact equality in European countries. Instead, we follow a rather descriptive approach by looking at successful direct democratic votes and their impact on equality in order to see if interesting patterns emerge that can then serve as the basis for further, more in-depth, analysis. Before presenting our results, we give a brief overview of the empirical literature on direct democracy and equality, with a special focus on the few articles that actually differentiated between direct democratic instruments.

\section{State of the Art}

As options for and the use of direct democracy are increasing, several scholars have addressed its effects on equality in recent years. As mentioned earlier, they ei- 
ther concentrate on aspects of socioeconomic equality or investigate political and/or legal equality of minorities. Most of the research has concentrated on the US and Switzerland and many scholars analyzed the effect of the existence of direct democratic options instead of the outputs of concrete bills. Moreover, only few studies differentiated between direct democratic instruments.

The following section will briefly summarize the findings of previous studies that dealt with the impact of direct democracy on equality. We will first present those findings that are mainly concerned with socioeconomic equality and, in a second step, present those that deal with legal and political equality. In the two parts we will consider both studies that look at direct democracy in general and studies that explicitly differentiate between different direct democratic instruments.

For the first part-namely regarding the impact of direct democracy on socioeconomic equality-it can be said that the negative assumption by Wolfgang Merkel $(2011,2015)$ is backed up by a number of empirical results: educative spending is lower in US states with direct democratic options and resourceful groups benefitted at the expense of worse-off in some German direct democratic votes (Berry, 2014; Schäfer \& Schoen, 2013; Töller \& Vollmer, 2013). Also, several studies found that Swiss cantons or US states with more direct democratic options invest less in social spending (Berry, 2009; Feld \& Kirchgässner, 2000; Freitag \& Vatter, 2006; Matsusaka, 2004; Moser \& Obinger, 2007; Wagschal \& Obinger, 2000). While this is usually assumed to result in less socioeconomic equality, Feld et al. (2010) actually observe no effect of differences in welfare spending on levels of income equality in Swiss cantons with more or less direct democratic options. Moreover, findings by Fatke (2014, p. 112) suggest that "there is no evidence that SES affects participation in direct democracies significantly more or less than in representative systems", which generally speaks against Merkel's (2011) rather pessimistic argumentation regarding direct democracy.

The only studies in this regard that differentiate between direct democratic instruments find contrasting patterns: while countries with national initiatives tend to spend more on welfare, expenditures are lower in countries with mandatory referenda (Blume et al., 2009; Blume \& Voigt, 2012). Also, the use of mandatory fiscal referenda decreases redistribution through personal income taxes in Swiss cantons in the short run, while the use of initiatives increases it in the long run (Morger \& Schaltegger, 2018). This might tempt one to assume a negative effect of mandatory referenda on socioeconomic equality, and a positive one of bottom-up referenda. However, it is important to note that the authors of the cross-national analysis investigate the legal existence of direct democratic options and not their actual use and outputs.

When it comes to the impact of direct democracy on legal and political equality, results are even more mixed. While Gamble (1997), Haider-Markel, Querze, and Lindaman (2007), and Lewis (2013) emphasize the negative implications of direct democracy in USAmerican states for (at least some) minority groups, Frey and Goette (1998) find minority rights to be protected by referenda in Switzerland. Regarding political equality, Flavin (2013, p. 130) indicates that a frequent use of initiatives in American states "may be a viable avenue for ensuring that the opinions of disadvantaged citizens are represented in the political arena". The majority of studies on both countries arrives at somewhat nuanced conclusions: context conditions seem to determine whether minorities are discriminated against in the US, and characteristics of the respective minority groups might be decisive for whether their rights are endangered or protected through direct democracy in Switzerland (Bollinger, 2007; Christmann \& Danaci, 2012; Donovan \& Bowler, 1998; Hajnal, Gerber, \& Louch, 2002; Helbling \& Kriesi, 2004; Vatter, 2000; Vatter \& Danaci, 2010).

Regarding different effects depending on the direct democratic instrument employed, empirical studies are again scarce, but do point in one direction: Gamble (1997) states that the discrimination against minorities in the US mainly happened via bottom-up referenda preventing parliament from protecting these groupsVatter and Danaci (2010) find bottom-up referenda significantly decreasing the probability of minority protection in Switzerland compared to mandatory referenda.

Overall, empirical results do not offer definite answers to the question of how direct democracy can be expected to impact equality. Regarding the socioeconomic dimension, the tendency is towards a negative effect, while context factors seem to make the difference. This is also especially true in case of legal and political equality. The few existing studies suggest positive effects of bottom-up referenda on socioeconomic equality, but negative ones on legal and political equality, while it might be the other way around for mandatory referenda.

Different instruments of direct democracy should certainly get more attention in terms of their possibly different effects on equality. This can be seen as one research gap in the current literature. Additionally, most studies in the field focus on the US or Switzerland and just one dimension of equality. The few existing comparative analyses mostly look at legal options of direct democracy without regarding actual direct democratic outputs - a fact that, as Berry (2014) shows, is at least somewhat problematic for the causal interpretation of results. Our article aims to take a first step in addressing these research gaps by looking at all national-level direct democratic bills in Europe from 1990 to 2015, and assessing their outputs for socioeconomic, legal and political equality, thereby differentiating between direct democratic instruments. With our results we provide a descriptive overview of how direct democratic outputs in Europe have addressed issues of equality. In the following, we will present our case selection, coding rules, and methodological challenges in more detail before presenting our results. 


\section{Coding and Data}

This article is part of the DFG-funded project "Inequality and Direct Democracy in Europe", which analyzes all direct democratic bills at subnational and national level in European democracies from 1990 to 2015 regarding their output for equality. In this article, we focus solely on successful bills at the national level.

For each successful bill, we assessed if the bill proposed measures that fostered or hampered socioeconomic, political or legal equality. Every bill that proposes measures that would help to close the gap between disadvantaged and better-off groups (by giving the greatest benefit to the worse-off or restricting benefits to the better-off) is considered as pro-equality. Vice versa, bills that would increase this gap (by giving further benefits to the better-off or restricting those to the worse-off) are considered as contra-equality.

This assessment of (potential) equality outputs of a bill is perhaps most straightforward regarding socioeconomic equality. We count as disadvantaged those social groups that are worse off than the general majority with regard to socioeconomic aspects such as income, education, housing or welfare. For legal equality, a bill has to propose measures that improve the legal situation of social groups that do not enjoy the same rights as other groups. Examples are the legalization of same-sex marriages or easier naturalization for long-term residents without citizenship. In order to count as pro-equality in political terms, bills have to propose measures that improve the situation of political minorities and thereby enable them to increase their political influence relative to powerful political mainstream actors. Political minorities are understood as groups whose political aims significantly differ from mainstream political actors (e.g., major parties) - with regard to the social or ethnical groups they primarily represent (e.g., Black Lives Matter Movement) or issues that they put on their agenda (e.g., Pirate Party).

For the coding, we have to keep in mind that the dimensions of socioeconomic, legal and political equality might sometimes overlap and cannot necessarily be seen as independent of each other. A rise of socioeconomic equality within a country is likely to also lead to more political or legal equality, and vice versa. However, for the coding process this was not a major problem as most successful pro- (or contra-) equality bills clearly aimed at one specific dimension of equality. For example, there were bills on extending welfare programs (socioeconomic equality), legalizing same-sex marriage (legal equality) or increasing proportional representation in parliament (political equality). In very few cases more than one dimension came into play, and with these we coded for that dimension on which the bill was mostly concerned with. As a result, bills were not coded pro- or contra-equality on multiple dimensions.

As mentioned earlier, we analyze all national-level direct democratic votes between 1990 and 2015 in
European democracies. We count as democratic all European countries that were considered free according to the Freedom House index in the year of the vote. To collect data on the votes and instruments employed, we drew on well-established online search engines for direct democracy such as www.sudd.ch or www.c2d.ch. Between 1990 and 2015, 515 direct democratic bills were voted upon in European democracies, of which 240 took place in Switzerland. 321 referenda were bottom-up, 116 mandatory and 78 top-down. Figure 1 shows the distribution of all votes for each year.

Figure 1 reveals that the frequency of votes varied substantially over the years, with a minimum of 8 in 2007 and a maximum of 31 in 2003 . There has been no period of time when direct democracy was especially popular or rarely used at all-the peaks and troughs fluctuate quite regularly. Table 5 (see Appendix) presents a short overview of the countries included in our sample and gives information about which direct democratic instruments are available at the national level. While in some countries such as Norway or the Netherlands we find very few or no referenda at all, other countries such as Italy, Liechtenstein and-obviously-Switzerland make use of referenda quite frequently so that we find a lot of cases for these countries.

Out of our 515 bills, we had to exclude some from our sample. First, we excluded those without sufficient information on the content of the bill to evaluate its output for equality. Second, bills that proposed changes regarding direct democratic procedures were excluded, as keeping them would have required a judgment on the effects of direct democracy on equality-which is exactly what we are looking at. Third, we excluded bills that proposed highly complex measures, for example comprehensive tax systems overhauls. These would have required indepth case studies and therefore were out of the scope of this article. Fourth, bills on joining international organizations such as the EU or NATO were excluded. Membership in, for example, the EU has so many implications for so many aspects of equality that it is not possible to code it in a straightforward way.

Summing up, we only included those direct democratic bills in our sample for which we were able to make clear and sound judgments on their (possible) outputs for socioeconomic, legal or political equality. Table 1 gives you a few examples of bills that were excluded due to one of the reasons mentioned.

After the exclusion of those cases, we were left with 373 direct democratic bills in our sample. From this sample, we then only looked at those that were successful, meaning those that had an actual political output. We assessed, whether the measures that those bills proposed would foster or hinder equality on our three dimensions-or if they were not related to equality at all. Multiple sources were used for these assessments, such as the bill proposal itself, NGO reports, newspaper articles, political science articles and legal texts. A codebook with several key questions can be found in the Appendix 
35

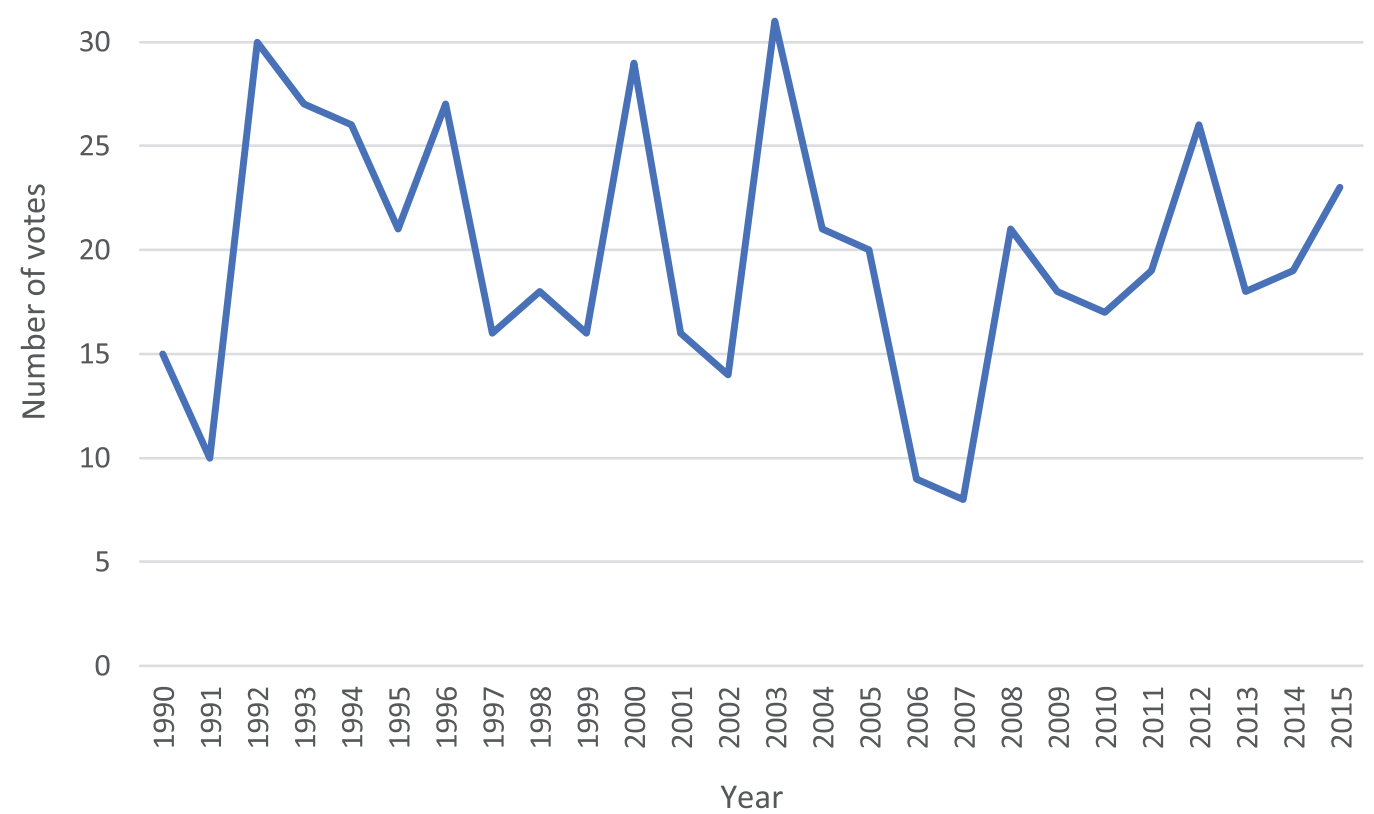

Figure 1. Direct democratic votes in European democracies 1990-2015 (national level).

Table 1. Examples of cases excluded from sample.

\begin{tabular}{|c|c|}
\hline Example & Reason for Exclusion \\
\hline $\begin{array}{l}\text { Referendum in Lithuania: } 8 / 27 / 1994 \\
\text { Referendum on indexing the value of } \\
\text { long-term capital investments }\end{array}$ & $\begin{array}{l}\text { Missing data: not enough information on the actual content of } \\
\text { the bill accessible }\end{array}$ \\
\hline $\begin{array}{l}\text { Referendum in San Marino: } 7 / 3 / 2005 \\
\text { Bill on introducing a } 40 \% \text { approval quorum } \\
\text { for direct democratic votes }\end{array}$ & Bill on direct democratic instruments \\
\hline $\begin{array}{l}\text { Referendum in Liechtenstein: 10/21/1990 } \\
\text { Bill on comprehensive tax reform }\end{array}$ & $\begin{array}{l}\text { Complex issue: comprehensive reform with multiple complex aspects to it, } \\
\text { no clear assessment of the effects regarding equality possible without } \\
\text { in-depth case study }\end{array}$ \\
\hline
\end{tabular}

of this article. To make the coding more reliable, it was undertaken by multiple researchers. For the whole sample, we arrived at a congruency of $93.2 \%$ and excluded only 6 cases which were coded differently by every coder. Table 2 shows some examples of pro- and contra-equality bills for each dimension:

Table 2. Core examples of pro- and contra-equality bills.

\begin{tabular}{llll}
\hline & Socioeconomic Equality & Political Equality & Legal Equality \\
\hline Pro Equality & $\begin{array}{l}\text { Hungary: 03/09/2008 } \\
\text { Referendum on abolition of } \\
\text { fees for higher public } \\
\text { education }\end{array}$ & $\begin{array}{l}\text { Liechtenstein: 08/11/1992 } \\
\text { Referendum on abolition of } \\
\text { the } 8 \% \text { threshold for } \\
\text { parliamentary elections }\end{array}$ & $\begin{array}{l}\text { Ireland: 05/22/2015 } \\
\text { Referendum on legalizing } \\
\text { same-sex marriage }\end{array}$ \\
\hline Non-Equality- & Switzerland: 04/01/1990 & Liechtenstein: 03/10/2002 & \\
Related & Initiative against highway & Referendum on raising funds & Lithuania: 06/14/1992 \\
& between Biel and & for the Little Big One music & of Soviet troops from \\
& Solothurn/Zuchwil & festival & Lithuania by end of 1992 \\
\hline Contra & Switzerland: 09/27/1998 & Poland: 09/06/2015 & Slovakia: 02/07/2015 \\
Equality & Referendum on reduction & Introduction of majoritarian voting & Referendum on banning \\
& of pensions for orphans & system for parliamentary elections & adoption by same-sex \\
& and widows & instead of proportional voting system & couples \\
\hline
\end{tabular}


We assessed the output of each bill, based on their title, the wording of the proposal or the data sources at hand, mentioned above. Additionally, some literature exists on most cases, helping us to make sound judgments regarding their connection to our equality dimensions. One example is a referendum in Italy that took place in 1995 , which aimed at restricting the number of private television channels owned by one person to one. While this at first glance does not seem to be related to equality, literature tells us that it was intended to limit the political influence of Silvio Berlusconi, thereby increasing political equality (Capretti, 2001; Tagliabue, 1995). It might be possible that bills we coded as not related to equality had effects on equality in their actual outcome (not output). To assess this, we would have had to do case studies of all of the 373 bills, which was beyond the scope of this article.

\section{Results}

In order to get an impression of the way in which the outputs of national-level direct democratic votes differ depending on the instrument used, Table 3 shows how many successful bills have pro-/contra-equality outputs and how many are not related to equality at all. It entails the three equality dimensions and total numbers, each differentiated between bottom-up, mandatory and top-down referenda. Cramér's V indicates whether there is a significant relationship between the instrument employed and the shares of pro- and contra-equality outputs and those bills that did not relate to equality. In total, 129 out of the 373 bills in our sample were adopted in a direct democratic vote-60 via bottom-up, 52 via mandatory, and 17 via top-down referenda.

When looking at Table 3, it first of all becomes clear that most of the adopted bills are not related to our equality dimensions at all. This is true for over $65 \%$ of all successful bills that are included in our analysis. Therefore, numbers for pro- and contra-equality outputs are relatively small and allow only for limited conclusions about differences between instruments and dimensions.

Nevertheless, there is a significant, moderate relationship between the direct democratic instrument and the distribution of pro-, contra- and non-equality-related outputs for every equality dimension and in total. The levels of significance are at $10 \%$ and $1 \%$ for political equality. This indicates that direct democratic instruments might indeed make a difference when it comes to the adoption of pro- and contra-equality bills, leaving all other things aside. In total, mandatory referenda produce (slightly) more outputs fostering equality than hindering it. For bottom-up and top-down referenda, the numbers are more balanced.

Turning to the single dimensions, first, we see a narrow but positive record for socioeconomic equality across all instruments except top-down referenda, of which none has an output related to equality. This is also the only dimension where bottom-up referenda result in more pro-equality outputs than in contra-equality ones. Second, only very few direct democratic outputs concern political equality and the numbers of pro- and contraoutputs are, more or less, balanced with only minor differences for bottom-up referenda. Finally, bottom-up referenda more often widen the gap between legally disadvantaged groups and the rest of society, thus decreasing legal equality. The opposite is true for mandatory and top-down referenda: their outputs more often increase than decrease legal equality. But here again, the numbers are very small and therefore differences should not be overestimated.

As Switzerland is a special case, both because of its long history of direct democracy and its widespread use, we repeated our tabulations without the Swiss cases. The respective results can be found in the Appendix (Table 6). Without the Swiss cases, the relationships between instruments and outputs lose their significance. This comes as no surprise as almost half of the bills are from Switzerland, and underlines the preliminary character of our findings and the need for further research on the topic. Still, there are some other differences in the results worth mentioning. The record of bottom-up referenda especially improves when excluding Switzerland: taking all equality dimensions together, they now result slightly more often in pro-equality outputs than in contraequality ones. While they still have a negative ratio regarding legal equality, it is not as distinct as it is when including the Swiss cases. When it comes to political equality, numbers for bottom-up referenda are now balanced. Patterns for mandatory and top-down referenda remain more or less the same, with the number of mandatory votes dropping considerably without the Swiss ones. The differences regarding bottom-up instruments, although only small in numbers, underline the importance of context when judging the output of direct democratic instruments: further research should investigate if the negative record for bottom-up votes for political and legal equality in Switzerland holds over a longer time period and, if yes, why this is the case, when in other countries outputs of these votes are more balanced.

Clearly, the results presented above might appear somewhat confusing at first glance. For this reason we have summarized them in Table 4.

In Table 4 you find an overview on the proportions of successful pro- and contra-equality bills for each direct democratic instrument and each equality dimension, including and excluding the Swiss cases. + stands for more pro-equality outputs, - for more contra-equality ones, and 0 for a balanced number of pro- and contraequality outputs.

Summing up, our findings make clear that a great majority of successful-national-level-direct democratic bills in Europe are not related to equality issues at all. Those differences that we find regarding different direct democratic instruments, different equality dimensions and the number of successful pro- and contra-equality bills are generally rather small. Generally, there are 
Table 3. Pro- and contra-equality outputs.

\begin{tabular}{|c|c|c|c|c|c|c|c|c|c|c|c|c|}
\hline & \multicolumn{3}{|c|}{ Socioeconomic Equality } & \multicolumn{3}{|c|}{ Political Equality } & \multicolumn{3}{|c|}{ Legal Equality } & \multicolumn{3}{|c|}{ Total } \\
\hline & Bottom-up & Mandatory & Top-down & Bottom-up & Mandatory & Top-down & Bottom-up & Mandatory & Top-down & Bottom-up & Mandatory & Top-down \\
\hline $\begin{array}{l}\text { Pro } \\
\text { Equality } \\
(+1)\end{array}$ & $\begin{array}{c}9 \\
(15 \%)\end{array}$ & $\begin{array}{c}7 \\
(13.46 \%)\end{array}$ & $\begin{array}{c}0 \\
(0 \%)\end{array}$ & $\begin{array}{c}1 \\
(1.67 \%)\end{array}$ & $\begin{array}{c}0 \\
(0,00 \%)\end{array}$ & $\begin{array}{c}2 \\
(11.76 \%)\end{array}$ & $\begin{array}{c}1 \\
(1.67 \%)\end{array}$ & $\begin{array}{c}4 \\
(7.69 \%)\end{array}$ & $\begin{array}{c}2 \\
(11.76 \%)\end{array}$ & $\begin{array}{c}11 \\
(18.33 \%)\end{array}$ & $\begin{array}{c}11 \\
(21.15 \%)\end{array}$ & $\begin{array}{c}4 \\
(23.53 \%)\end{array}$ \\
\hline $\begin{array}{l}\text { Non- } \\
\text { Equality- } \\
\text { Related (0) }\end{array}$ & $\begin{array}{c}47 \\
(78.33 \%)\end{array}$ & $\begin{array}{c}45 \\
(86.54 \%)\end{array}$ & $\begin{array}{c}17 \\
(100 \%)\end{array}$ & $\begin{array}{c}56 \\
(93.33 \%)\end{array}$ & $\begin{array}{c}52 \\
(100 \%)\end{array}$ & $\begin{array}{c}13 \\
(76.47 \%)\end{array}$ & $\begin{array}{c}51 \\
(85 \%)\end{array}$ & $\begin{array}{c}47 \\
(90.38 \%)\end{array}$ & $\begin{array}{c}15 \\
(88.24 \%)\end{array}$ & $\begin{array}{c}34 \\
(56.67 \%)\end{array}$ & $\begin{array}{c}40 \\
(76.92 \%)\end{array}$ & $\begin{array}{c}11 \\
(64.71 \%)\end{array}$ \\
\hline $\begin{array}{l}\text { Contra } \\
\text { Equality } \\
(-1)\end{array}$ & $\begin{array}{c}4 \\
(6.67 \%)\end{array}$ & $\begin{array}{c}0 \\
(0.00 \%)\end{array}$ & $\begin{array}{c}0 \\
(0 \%)\end{array}$ & $\begin{array}{c}3 \\
(5 \%)\end{array}$ & $\begin{array}{c}0 \\
(0 \%)\end{array}$ & $\begin{array}{c}2 \\
(11.76 \%)\end{array}$ & $\begin{array}{c}8 \\
(13.33 \%)\end{array}$ & $\begin{array}{c}1 \\
(1.92 \%)\end{array}$ & $\begin{array}{c}0 \\
(0 \%)\end{array}$ & $\begin{array}{c}15 \\
(25 \%)\end{array}$ & $\begin{array}{c}1 \\
(1.92 \%)\end{array}$ & $\begin{array}{c}2 \\
(11.76 \%)\end{array}$ \\
\hline $\begin{array}{l}\text { Number } \\
\text { of Votes } \\
\text { (Total) }\end{array}$ & $\begin{array}{c}60 \\
(100 \%)\end{array}$ & $\begin{array}{c}52 \\
(100 \%)\end{array}$ & $\begin{array}{c}17 \\
(100 \%)\end{array}$ & $\begin{array}{c}60 \\
(100 \%)\end{array}$ & $\begin{array}{c}52 \\
(100 \%)\end{array}$ & $\begin{array}{c}17 \\
(100 \%)\end{array}$ & $\begin{array}{c}60 \\
(100 \%)\end{array}$ & $\begin{array}{c}52 \\
(100 \%)\end{array}$ & $\begin{array}{c}17 \\
(100 \%)\end{array}$ & $\begin{array}{c}60 \\
(100 \%)\end{array}$ & $\begin{array}{c}52 \\
(100 \%)\end{array}$ & $\begin{array}{c}17 \\
(100 \%)\end{array}$ \\
\hline Cramér's V & & $0.1746 *$ & & & $0.2290^{* * *}$ & & & $0.1966 * *$ & & & $0.2215^{* *}$ & \\
\hline
\end{tabular}

Notes: ${ }^{*}=10 \%$ significance $\left(\mathrm{Chi}^{2}\right) ; * *=5 \%$ significance $\left(\mathrm{Chi}^{2}\right) ; * * *=1 \%$ significance $\left(\mathrm{Chi}^{2}\right)$. 
Table 4. Overview of the proportions of pro- and contra equality outputs/bills.

\begin{tabular}{lcccccc}
\hline & \multicolumn{2}{c}{ Bottom-Up } & \multicolumn{2}{c}{ Mandatory } & \multicolumn{2}{c}{ Top-Down } \\
\cline { 2 - 8 } & $\begin{array}{c}\text { Incl. } \\
\text { Switzerland }\end{array}$ & $\begin{array}{c}\text { Excl. } \\
\text { Switzerland }\end{array}$ & $\begin{array}{c}\text { Incl. } \\
\text { Switzerland }\end{array}$ & $\begin{array}{c}\text { Excl. } \\
\text { Switzerland }\end{array}$ & $\begin{array}{c}\text { Incl. } \\
\text { Switzerland }\end{array}$ & Switzerland \\
\hline Socioeconomic Equality & + & $(+)$ & + & $(+)$ & 0 & 0 \\
\hline Political Equality & - & 0 & 0 & 0 & 0 & 0 \\
\hline Legal Equality & - & $(-)$ & + & $(+)$ & + & $(+)$ \\
\hline
\end{tabular}

Notes: the parentheses () indicate that the relationship between direct democratic instrument and equality output is insignificant.

slightly more pro-equality outputs than contra- oneswhich is especially true for socioeconomic equality. As Table 4 indicates, mandatory referenda produce more pro- than contra-equality outputs, for both the socioeconomic and the legal equality dimension-again keeping in mind that we are talking about minor differences here. Bottom-up referenda produce slightly more proequality outputs on the socioeconomic dimension but also slightly more contra-equality ones for legal equality. All in all, it is important to keep in mind that these results stem from a very limited number of cases-a majority of the national-level direct democratic outputs analyzed in our article do not relate to equality at all, and differences between the instruments lose significance when omitting Switzerland. Therefore, the findings presented in Table 4 are only first impressions that can serve as a starting point for future research on the topic.

\section{Conclusions}

In this article, we have dealt with the question of whether there are, at the national level, more successful pro- or contra-equality bills that passed via different direct democratic instruments (bottom-up, top-down and mandatory referenda) during the last decades in European democracies. In order to answer this, we built on three equality-dimensions-namely socioeconomic, political, and legal equality - and we drew on a dataset of all national-level referenda in European democracies from 1990 to 2015.

The aim of the article was to gain a first impression of the relationship between direct democratic instruments and equality by presenting descriptive statistics, thereby encouraging further analytical, in-depth research. In order to give an overview that is as encompassing as possible while at the same time sticking to a reliable coding procedure, we had to exclude those direct democratic votes where the output in equality terms could not be evaluated in a straightforward way. Of course it may be that the excluded cases would show a picture that is completely different from the one we present now. Nevertheless, we are able to make statements about a majority of the national-level bills that were voted on in our studied period-namely 373 out of 515 bills in total, and 129 successful ones.
Our first major finding was that most of the remaining outputs were not related to any of the three equalitydimensions at all-somewhat easing concerns about direct democracy as a serious threat to equality, but at the same time limiting its promises as a potential "road to equality". This left us with relatively small numbers of pro- versus contra-equality outputs and differences between those. We therefore cannot draw generalized conclusions from our findings. Nevertheless, some patterns emerged that deserve further investigation.

First, our results indicate that the outputs of bottomup referenda fostered socioeconomic equality slightly more often than hindered it-a finding that fits the theoretical assumption that minority groups (in this case low SES ones) can use this direct democratic instrument to foster their interests. However, it was the other way around for legal equality, where bottom-up votes slightly more often hindered than fostered equality. This might support previous findings on the negative impact of bottom-up referenda on minority protection (Gamble, 1997; Vatter \& Danaci, 2010).

Second, the bivariate test of the relationship between instruments of direct democracy and equality hints to a relatively good record of mandatory referenda in terms of fostering equality. This might speak against the findings by Blume et al. (2009) and Blume and Voigt (2012) on the option for this instrument resulting in less welfare spending. However, three things are important here: first of all, in our dataset only seven national-level mandatory votes resulted in an output that was related to socioeconomic equality at all. While all of these outputs were pro-equality, such a small number of cases without controls does not allow for major inferences. Second, if our finding would also hold in replications covering more cases and including context factors, the differentiation between option and use became apparent: the opportunity to hold mandatory referenda does not necessarily mean that they are also employed-at all or with regard to welfare spending. Therefore, it is quite difficult to come to solid conclusions about the influence of direct democracy on socioeconomic equality by only looking at legal options. While this might capture indirect effects of direct democracy, the direct effects of actual votes are ignored. Third, confirmation of our findings would also point to the importance of taking 
other aspects of socioeconomic equality besides welfare spending into account.

Generally, this article is a first attempt to look at the outputs of successful direct democratic bills in Europe with regard to equality. In our investigation of all national-level referenda from 1990 to 2015, we have discovered some interesting patterns but the limited character of our findings does not allow for any final conclusions. Instead, future research can investigate if similaror different-patterns emerge when taking into account more cases and also when looking at potential context factors. Clearly, a number of different aspects such as citizens' attitudes towards minorities, the composition of the electorate, interactions between direct democratic instruments and the representative system, the general level of equality in a country, or the existence of voting and approval quora could play an important role in this context. Therefore, in order to arrive at a deeper understanding of the matter, it would be necessary for future research projects to look at these factors in detail. The results of this article give us first ideas of how different direct instruments have had an impact on equality in Europe and can serve as a starting point for such future research projects.

\section{Acknowledgments}

We thank the German Research Foundation (DFG) for their funding of the research project "Inequality and Direct Democracy in Europe".

\section{Conflict of Interests}

The authors declare no conflict of interests.

\section{References}

Alexy, R. (1986). Theorie der Grundrechte [Theory of basic rights] (7th ed.). Berlin: Suhrkamp.

Altwicker, T. (2011). Menschenrechtlicher Gleichheitsschutz [International equality protection law]. Wiesbaden: Springer VS.

Berry, C. R. (2009). Direct democracy and redistribution (Working Paper, No. 09.05). Chicago, IL: University of Chicago.

Berry, C. R. (2014). Direct versus representative democracy: Reassessing the fiscal effects. Unpublished manuscript.

Black, D. (1948). On the rationale of group decisionmaking. The Journal of Political Economy, 56(1), 23-34.

Blume, L., \& Voigt, S. (2012). Institutional details matter: More economic effects of direct democracy. Economics of Governance, 13(4), 287-310.

Blume, L., Müller, J., \& Voigt, S. (2009). The economic effects of direct democracy: A first global assessment. Public Choice, 140(3), 431-461.

Bollinger, C. (2007). Minderheiten in der direkten Demokratie [Minorities in direct democracy]. In $\mathrm{M}$.
Freitag \& U. Wagschal (Eds.), Direkte Demokratie. Bestandsaufnahmen und Wirkungen im internationalen Vergleich [Direct democracy: inventory and effects in international comparison] (pp. 419-446). Berlin: LIT Verlag.

Bowler, S., Denemark, D., Donovan, T., \& McDonnell, D. (2017). Right-wing populist party supporters: Dissatisfied but not direct democrats. European Journal of Political Research, 56(1), 70-91.

Capretti, A. (2001). Öffnung der Machtstrukturen durch Referenden in Italien [Opening power structures through referenda in Italy]. Frankfurt am Main: Europäischer Verlag der Wissenschaft.

Christmann, A., \& Danaci, D. (2012). Direct democracy and minority rights: Direct and indirect effects on religious minorities in Switzerland. Politics and Religion, 5(1), 133-160.

Dalton, R. J. (2004). Democratic challenges, democratic choices. The erosion of political support in advanced industrial democracies. Oxford: Oxford University Press.

Devins, N., \& Douglas, D. M. (1998). Introduction: The pursuit of equality. In N. Devins \& D. M. Douglas (Eds.), Redefining equality (pp. 1-12). New York, NY: Oxford University Press.

Donovan, T., \& Bowler, S. (1998). Direct democracy and minority rights: An extension. American Journal of Political Science, 42(3), 1020-1024.

Downs, A. (1957). An economic theory of democracy. New York, NY: Harper \& Brothers.

Eder, C., \& Magin, R. (2008). Direkte Demokratie. In M. Freitag \& A. Vatter (Eds.), Die Demokratien der deutschen Bundesländer [Democracy in the German federal states] (pp. 257-308). Opladen and Farmington Hills: Verlag Barbara Budrich.

Fatke, M. (2014). Participation and political equality in direct democracy: Educative effect or social bias? Swiss Political Science Review, 21(1), 99-118.

Feld, L. P., Fischer, J. A. V., \& Kirchgässner, G. (2010). The effect of direct democracy on income redistribution: Evidence for Switzerland. Economic Inquiry, 48(4), 817-840.

Feld, L. P., \& Kirchgässner, G. (2000). Direct democracy, political culture, and the outcome of economic policy: A report on the Swiss experience. European Journal of Political Economy, 16(2), 287-306.

Flavin, P. (2013). Direct democracy and political equality in the American States. Paper presented at the annual meeting of the American Political Science Association, New Orleans, LA.

Freitag, M., \& Vatter, A. (2006). Initiatives, referendums, and the tax state. Journal of European Public Policy, 13(1), 89-112.

Frey, B. S., \& Goette, L. (1998). Does the popular vote destroy civil rights? American Journal of Political Science, 42(4), 1343-1348.

Gamble, B. S. (1997). Putting civil rights to a popular vote. American Journal of Political Science, 41(1), 245-269. 
Garry, J. (2013). Direct democracy and regional integration: Citizens' perceptions of treaty implications and the Irish reversal on Lisbon. European Journal of Political Research, 52(1), 94-118.

Haider-Markel, D. P., Querze, A., \& Lindaman, K. (2007). Lose, win, or draw? A reexamination of direct democracy and minority rights. Political Research Quarterly, 60(2), 304-314.

Hajnal, Z. L., Gerber, E. R., \& Louch, H. (2002). Minorities and direct legislation: Evidence from California ballot proposition elections. The Journal of Politics, 64(1), 154-177.

Helbling, M., \& Kriesi, H. (2004). Staatsbürgerverständnis und politische Mobilisierung: Einbürgerungen in Schweizer Gemeinden [Citizenship and political mobilization: naturalization in Swiss municipalities]. Swiss Political Science Review, 10(4), 33-58.

Lewis, D. (2013). Direct democracy and minority rights: $A$ critical assessment of the tyranny of the majority in the American states. New York, NY: Routledge.

Matsusaka, J. G. (2004). For the many or the few. The initiative, public policy, and American democracy. Chicago, IL: University of Chicago Press.

Merkel, W. (2011). Volksabstimmungen: Illusion und Realität [Referenda: Illusion and reality]. Aus Politik und Zeitgeschichte, 61(44/45), 47-55.

Merkel, W. (2015). Nur schöner Schein? Demokratische Innovationen in Theorie und Praxis [Just veneer? Democratic innovations in theory and practice] (OBSArbeitsheft 80). Berlin: Friedrich-Ebert-Stiftung.

Merkel, W., \& Ritzi, C. (2017). Die Legitimität Direkter Demokratie. Wie demokratisch sind Volksabstimmungen? [Legitimacy in direct democracy. How democratic are referenda?]. Wiesbaden: Springer VS.

Michels, A. (2009). Ideological positions and the referendum in the Netherlands. In M. Setälä \& T. Schiller (Eds.), Referendums and representative democracy: Responsiveness, accountability and deliberation (pp. 56-74). Abingdon: Routledge.

Morger, M., \& Schaltegger, C. A. (2018). Income tax schedule and redistribution in direct democracies: The Swiss case. Journal of Economic Inequality, 16(3), 413-438.

Moser, J., \& Obinger, H. (2007). Schlaraffenland auf Erden? Auswirkungen von Volksentscheiden auf die Sozialpolitik [Paradise on earth? Effects of referenda on social policies]. In M. Freitag \& U. Wagschal (Eds.), Direkte Demokratie. Bestandsaufnahmen und Wirkungen im internationalen Vergleich
[Direct democracy: Inventory and effects in international comparison] (pp. 331-362). Berlin: LIT Verlag.

Rawls, J. (1971). A theory of justice. Cambridge, MA: Harvard University Press.

Sartori, G. (1992). Gleichheit [Equality]. In G. Sartori (Ed.), Demokratietheorie [Democratic theory] (pp. 326-354). Darmstadt: Wissenschaftliche Buchgesellschaft.

Schäfer, A., \& Schoen, H. (2013). Mehr Demokratie, aber nur für Wenige? Der Zielkonflikt zwischen mehr Beteiligung und Politischer Gleichheit [More democracy but only for a few? Conflicts between more participation and political equality]. Leviathan, 41(1), 94-120.

Siegel, R. (1998). Civil rights reform in historical perspective: Regulating martial violence. In N. Devins \& D. M. Douglas (Eds.), Redefining equality (pp. 29-50). New York, NY: Oxford University Press.

Strauss, D. (1992). The illusory distinction between equality of opportunity and equality of result. William \& Mary Law Review, 34(1), 171-188.

Tagliabue, J. (1995). Italian referendum may break up Berlusconi's TV interests. The New York Times. Retrieved from https://www.nytimes.com/1995/ 06/11/world/italian-referendum-may-break-upberlusconi-s-tv-interests.html

Töller, A., \& Vollmer, A. (2013). Wem nützt Direkte Demokratie? Policy-Effekte Direkter Demokratie und Folgerungen für die Forschung zu Deutschland [Who benefits from direct democracy? Policy-effects and implications for research in Germany]. Zeitschrift Für Vergleichende Politikwissenschaft, 7(4), 299-320.

Vatter, A. (2000). Consensus and direct democracy: Conceptual and empirical linkages. European Journal of Political Research, 38(2), 171-192.

Vatter, A., \& Danaci, D. (2010). Mehrheitstyrannei durch Volksentscheide? Zum Spannungsverhältnis zwischen Direkter Demokratie und Minderheitenschutz [Tyranny of the majority through referenda? On the relationship between direct democracy and minority protection]. Politische Vierteljahresschrift, 51(2), 205-222.

Wagschal, U., \& Obinger, H. (2000). Der Einfluss der Direktdemokratie auf die Sozialpolitik [The effects of direct democracy on social policies]. Politische Vierteljahresschrift, 41(3), 466-497.

Westen, P. (2016). Speaking of equality: An analysis of the rhetorical force of "equality" in moral and legal discourse. Princeton, NJ: Princeton University Press.

\section{About the Authors}

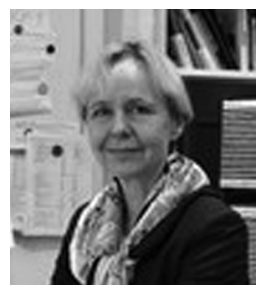

Brigitte Geissel, Goethe University Frankfurt, Professor of Political Science and Political Sociology, Head of Research Unit "Democratic Innovations". Her research interests include democratic innovations, new forms of governance and political actors (new social movements, associations, civil society, parties, political elites, citizens); recent publications e.g., in Political Studies Review, Representation, Political Studies, International Political Science Review. 


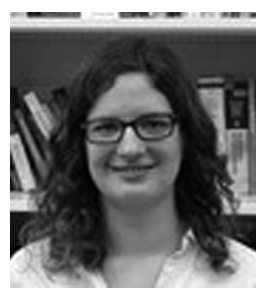

Anna Krämling, Goethe University Frankfurt, PhD student and Research Fellow at the chair of Prof. Dr. Brigitte Geissel, Research Unit "Democratic Innovations". Her research interests include direct democracy, minorities, political attitudes and quantitative social research.

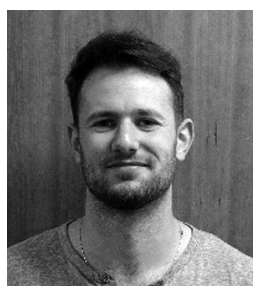

Lars Paulus, Goethe University Frankfurt, PhD student and Research Fellow at the chair of Prof. Dr. Brigitte Geissel, Research Unit “Democratic Innovations". His research interests include direct democracy, political culture and empirical social research, in particular Qualitative Comparative Analysis. 


\section{Appendix}

Table 5. Overview of available direct democratic instruments in European democracies.

\begin{tabular}{|c|c|c|c|}
\hline Country & Bottom-Up* & Top-Down** & Mandatory \\
\hline Andorra & No & Yes & Yes \\
\hline Austria & No & Yes & Yes \\
\hline Belgium & No & No & No \\
\hline Bulgaria & Yes & Yes & No \\
\hline Croatia & Yes & Yes & Yes \\
\hline Cyprus & No & No*** & No \\
\hline Cyprus (North) & No & Yes & No \\
\hline Czech Republic & No & No*** & No \\
\hline Denmark & No & Yes & Yes \\
\hline Estonia & & Yes & Yes \\
\hline Finland & No & Yes & No \\
\hline France & No & Yes & Yes \\
\hline Germany & No & No & Yes \\
\hline Gibraltar & No & Yes & Yes \\
\hline Greece & No & Yes & No \\
\hline Hungary & Yes & Yes & Yes \\
\hline Iceland & No & Yes & Yes \\
\hline Ireland & No & Yes & Yes \\
\hline Italy & Yes & Yes & No \\
\hline Latvia & Yes & Yes & Yes \\
\hline Liechtenstein & Yes & Yes & Yes \\
\hline Lithuania & Yes & Yes & Yes \\
\hline Luxembourg & Yes & Yes & No \\
\hline Malta & Yes & Yes & Yes \\
\hline Netherlands & No & No & No \\
\hline Norway & No & No*** & No \\
\hline Poland & No & Yes & No \\
\hline Portugal & Yes & Yes & Yes \\
\hline Romania & No & Yes & Yes \\
\hline Serbia & Yes & Yes & Yes \\
\hline Slovakia & Yes & Yes & Yes \\
\hline Slovenia & No & Yes & No \\
\hline Spain & No & Yes & Yes \\
\hline Sweden & No & Yes & No \\
\hline Switzerland & Yes & Yes & Yes \\
\hline United Kingdom & No & Yes & Yes \\
\hline
\end{tabular}

Notes: * Includes those that are listed as citizen initiative by IDEA; ** Includes those that are listed as optional referendums by IDEA; *** but ad hoc referendums are possible. Source: International Institute for Democracy and Electoral Assistance (n.d.). 


\section{Codebook}

\begin{tabular}{ll}
\hline Dimension & Guiding Questions \\
(Code pro-equality if any of these questions can be answered with "yes" except 1.8)
\end{tabular}

1. Socioeconomic Equality 1.1) Does the bill propose measures that will increase income for low SES groups? (i.e., raising the minimum wage, give tax cuts to low income people, raising pensions etc.)

1.2) Does the bill propose measures that make (higher) education more affordable for low SES groups?

1.3) Does the bill propose measures that make healthcare more affordable for low SES groups? Does it lower patient contributions in the health care sector?

1.4) Does the bill propose measures that make housing more affordable for low SES groups? (i.e., raising housing subsidies, expand public housing, etc.)

1.5) Does the bill propose measures that expand social welfare programs?

1.6) Does the bill propose measures that abolish/lower other kinds of fees that are not proportionally rising with income?

1.7) Does the bill propose measures to invest in common goods mainly benefitting low SES groups? (e.g., public transportation)

1.8) Does the bill propose measures that increase the retirement age? (if yes code contra-equality)

2. Political Equality

2.1) Does the bill propose measures that strengthen the political voice/powers of (political) minorities?

2.2) Does the bill propose measures that lead to a more proportional composition of parliament? (i.e., get rid of/weaken majoritarian voting procedures, get rid of certain $\%$ thresholds for parliamentary elections)

2.3) Does the bill propose measures that increase the media presence of (political) minorities? Does it propose measures against media monopolies of certain political actors?

3. Legal Equality

3.1) Does the bill propose measures that give more legal rights to disadvantaged groups? (i.e., allowing same-sex marriage, allowing adoption for same-sex couples, allowing permanent residents without citizenship to vote in elections, etc.)

3.2) Does the bill propose measures that facilitate the way to citizenship? (i.e., for immigrants that are long-term residents of the country, for children of immigrants that were born/raised in the country, etc.)

3.3) Does the bill propose measures that give more rights to immigrants/asylum seekers? Does it increase protection against deportation?

3.4) Does the bill propose measures that improve the legal status of foreign residents of a country? (i.e., allow them to buy property, allow them to work in certain professional fields, make them eligible to apply for social welfare programs/unemployment benefits, etc.) 
COGITATIO

Table 6. Pro- and contra-equality outputs without Switzerland.

\begin{tabular}{|c|c|c|c|c|c|c|c|c|c|c|c|c|}
\hline & \multicolumn{3}{|c|}{ Socioeconomic Equality } & \multicolumn{3}{|c|}{ Political Equality } & \multicolumn{3}{|c|}{ Legal Equality } & \multicolumn{3}{|c|}{ Total } \\
\hline & Bottom-Up & Mandatory & Top-Down & Bottom-Up & Mandatory & Top-Down & Bottom-Up & Mandatory & Top-Down & Bottom-Up & Mandatory & Top-Down \\
\hline $\begin{array}{l}\text { Pro } \\
\text { Equality } \\
(+1)\end{array}$ & $\begin{array}{c}3 \\
(11.54 \%)\end{array}$ & $\begin{array}{c}1 \\
(7.14 \%)\end{array}$ & $\begin{array}{c}0 \\
(0 \%)\end{array}$ & $\begin{array}{c}1 \\
(3.85 \%)\end{array}$ & $\begin{array}{c}0 \\
(0 \%)\end{array}$ & $\begin{array}{c}2 \\
(11.76 \%)\end{array}$ & $\begin{array}{c}1 \\
(3.85 \%)\end{array}$ & $\begin{array}{c}2 \\
(14.29 \%)\end{array}$ & $\begin{array}{c}2 \\
(11.76 \%)\end{array}$ & $\begin{array}{c}5 \\
(19.23 \%)\end{array}$ & $\begin{array}{c}3 \\
(21.43 \%)\end{array}$ & $\begin{array}{c}4 \\
(23.53 \%)\end{array}$ \\
\hline $\begin{array}{l}\text { Non- } \\
\text { Equality- } \\
\text { Related (0) }\end{array}$ & $\begin{array}{c}23 \\
(88.46 \%)\end{array}$ & $\begin{array}{c}13 \\
(92.86 \%)\end{array}$ & $\begin{array}{c}17 \\
(100 \%)\end{array}$ & $\begin{array}{c}24 \\
(92.13 \%)\end{array}$ & $\begin{array}{c}14 \\
(100 \%)\end{array}$ & $\begin{array}{c}13 \\
(76.47 \%)\end{array}$ & $\begin{array}{c}22 \\
(84.62 \%)\end{array}$ & $\begin{array}{c}11 \\
(78.57 \%)\end{array}$ & $\begin{array}{c}15 \\
(88.24 \%)\end{array}$ & $\begin{array}{c}17 \\
(65.38 \%)\end{array}$ & $\begin{array}{c}10 \\
(71.43 \%)\end{array}$ & $\begin{array}{c}11 \\
(64.71 \%)\end{array}$ \\
\hline $\begin{array}{l}\text { Contra } \\
\text { Equality } \\
(-1)\end{array}$ & $\begin{array}{c}0 \\
(0 \%)\end{array}$ & $\begin{array}{c}0 \\
(0 \%)\end{array}$ & $\begin{array}{c}0 \\
(0 \%)\end{array}$ & $\begin{array}{c}1 \\
(3.85 \%)\end{array}$ & $\begin{array}{c}0 \\
(0 \%)\end{array}$ & $\begin{array}{c}2 \\
(11.76 \%)\end{array}$ & $\begin{array}{c}3 \\
(11.54 \%)\end{array}$ & $\begin{array}{c}1 \\
(7.14 \%)\end{array}$ & $\begin{array}{c}0 \\
(0 \%)\end{array}$ & $\begin{array}{c}4 \\
(15.38 \%)\end{array}$ & $\begin{array}{c}1 \\
(7.14 \%)\end{array}$ & $\begin{array}{c}2 \\
(11.76 \%)\end{array}$ \\
\hline $\begin{array}{l}\text { Number of } \\
\text { Votes } \\
\text { (Total) }\end{array}$ & $\begin{array}{c}26 \\
(100 \%)\end{array}$ & $\begin{array}{c}14 \\
(100 \%)\end{array}$ & $\begin{array}{c}17 \\
(100 \%)\end{array}$ & $\begin{array}{c}26 \\
(100 \%)\end{array}$ & $\begin{array}{c}14 \\
(100 \%)\end{array}$ & $\begin{array}{c}17 \\
(100 \%)\end{array}$ & $\begin{array}{c}26 \\
(100 \%)\end{array}$ & $\begin{array}{c}14 \\
(100 \%)\end{array}$ & $\begin{array}{c}17 \\
(100 \%)\end{array}$ & $\begin{array}{c}26 \\
(100 \%)\end{array}$ & $\begin{array}{c}14 \\
(100 \%)\end{array}$ & $\begin{array}{c}17 \\
(100 \%)\end{array}$ \\
\hline Cramér's V & & 0.1918 & & & 0.2078 & & & 0.1731 & & & 0.0763 & \\
\hline
\end{tabular}

\section{Reference}

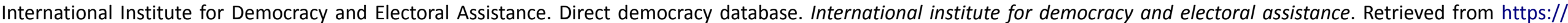
www.idea.int/data-tools/data/direct-democracy 